\title{
Giovanni Cacciavillani, Proust e l'adorazione perpetua. Il racconto della Recherche
}

\section{Emanuele Kanceff}

\section{Q OpenEdition}

1 Journals

\section{Edizione digitale}

URL: http://journals.openedition.org/studifrancesi/35132

DOI: 10.4000/studifrancesi.35132

ISSN: 2421-5856

\section{Editore}

Rosenberg \& Sellier

\section{Edizione cartacea}

Data di pubblicazione: 1 novembre 2005

Paginazione: 448

ISSN: 0039-2944

\section{Notizia bibliografica digitale}

Emanuele Kanceff, «Giovanni Cacciavillani, Proust e l'adorazione perpetua. I/ racconto della Recherche», Studi Francesi [Online], 146 (XLIX | II) | 2005, online dal 30 novembre 2015, consultato il 18 avril 2021. URL: http://journals.openedition.org/studifrancesi/35132 ; DOI: https://doi.org/10.4000/studifrancesi. 35132

Questo documento è stato generato automaticamente il 18 avril 2021.

\section{(c) (1)}

Studi Francesi è distribuita con Licenza Creative Commons Attribuzione - Non commerciale - Non opere derivate 4.0 Internazionale. 


\title{
Giovanni Cacciavillani, Proust e l'adorazione perpetua. Il racconto della Recherche
}

\author{
Emanuele Kanceff
}

\section{NOTIZIA}

GIOVANNI CACCIAVILLANI, Proust e l'adorazione perpetua. Il racconto della Recherche, Roma, Donzelli Editore, 2004, 183 p.

1 Ancora una lettura di Proust, si sarà tentati di dire. Ma questa di Cacciavillani si raccomanda per la raffinatezza e la sensibilità che mostra,oltre che per una piacevole scrittura che la impone all'attenzione del lettore come se fosse un romanzo. Veramente «racconto della Recherche», la sua trama si snocciola attraverso brevi e intensi capitoli che ci ricostriuscono davanti agli occhi gli intendimenti dello scrittore, il romanzo proustiano e le interessanti vicende della sua scrittura, quasi facendoci rigustare come nuovo e inedito il capolavoro narrativo del Novecento. 